\title{
The Impact of Individual Characteristics and Organization Culture on Performance and Career Development of Employees Case studies Five Star Hotel in Surabaya Indonesia
}

\author{
Dr. Hj. Musriha, Dra. Ec., MSi ${ }^{1}$ \\ ${ }^{1}$ (Management Department,Bhayangkara University, Surabaya, Indonesia)
}

\begin{abstract}
This research examines the impact of individual characteristics, organizational culture implementation toward performance and career improvement of the employees at Five Star Hotels Surabaya in Indonesia. This research was conducted at five star hotels in Surabaya which covered 100 employees as respondent. This research by utilizing Structural Equation Modelling (SEM), the technique was processed with AMOS program to analyze some hypothesis. The result of this research were empirical date of the development of the theoretical of human resources and practice management. The inter-correlations models between these variables in this study revealed that five hypothesis have significant correlation.
\end{abstract}

Keywords: individual characteristics, Organizational Culture, Performance and career improvement.

\section{INTRODUCTION}

The role of HR is becomes importance in the organization nowadays. It becomes particularly important to further improve the competence of the management of human resources management in each company in order to achieve organizational goals effectively and efficiently. Recognition of the importance of the role of human capital lead to increased research in the field of human resource management (HRM), generally on labor management in a company. To ensure employees have the knowledge and skills required, training and other human resource development activities should be carried out. Such activities will affect the climate in the $\mathrm{k} f$ the company, the performance and career development of employees.

Hotel is one of the known forms of accommodation in the tourism industry. It has been mentioned that the accommodation is a place for someone to stay for a while. These accommodations can include hotels, inns, guest house, lodge, cottage, inn, campground, and so on. Among the various forms of tourism services and activities which would be very important is the hotel. In the hotel to get some accommodation for the needs of travelers. Hotel is building as a place to live (relatively) temporary. Soekadijo (1996:91 [1]) states the hotels importance such as: "that the services provided at the hotel is the most important tourism services and the most comprehensive among all the tourism services". Foster et al. (200 0:20 [2]) says that the growth of the hospitality business cannot be separated from the growth and development of tourism. Qualifying employees who are in the hospitality services should be familiar with various cultures, the values of society and various social ethics both nationally, regionally and inter nationally. Schuster et al. (1999: 21 [3]) states that the concept of culture in a very broad sense is the total of the mind, work, and the work of people who are not rooted to his instincts, and therefore can only be triggered by humans after a learning process.

Individual characteristics that shapes employee behaviors that influence motivation, initiative, performance and career actualization for employees (Robbins, 1996: 109-111 [4]). As Robbins opinion, AREP and Asmara in Tanjung (2004:147 [5]) argues that, motivational factors inhibiting not only come from outside, but also from oneself (from the individual characteristics of each). Individual characteristics of hotel employees are very diverse, including tribal aspect, there are some tribes include: Javanese, Sundanese, Batak, and so on: this will affect the performance and the desire for a career. How the magnitude of the effect depends on the basic characteristics of the tribe. Other individual characteristics is the diversity of religious affiliations of employees, there are Islam, Christianity, Catholicism and others. Level of education is very diverse, with ethnic diversity, religion, level of education will certainly affect the performance and career development of employees of the hotel.

Furthermore, organizational culture will give employees the freedom to practice their faith, thus, organizational culture will make the employee feel satisfied with his work. Organizational culture will also create employee to comply with company regulations. Organizational effectiveness can be improved by creating a culture that will lead to the achievement of organizational objectives and at the same time will satisfy employees. O'Reilly et al. (1991 [6]) states, there is a relationship between the strength of organizational culture with the culture of employee selection and job satisfaction. Further Luthans (1998:144 [7]) states, job satisfaction is usually expressed in attitudes, for example, more loyal to the company, works well, dedicated to the company, orderly and comply with regulations and other attitudes that are positive. This means that when 
employees are satisfied with their jobs then the employee will be positive and at the same time the organization's objectives will be achieved. Organizational culture will give employees the freedom to practice their faith. Organizational effectiveness can be improved by creating a culture that will lead to the achievement of organizational objectives and at the same time will satisfy employees. O'Reilly et al. (1991 [6]) states, there is a relationship between the strength of organizational culture with the culture of employee selection and performance, with a strong organizational culture will be able to improve employee performance.

Performance is the result of work that can be achieved by a person or group of people in the organization in order to achieve organizational goals. Vroom in As'ad (2001:59 [8]) says that if an employee's performance is low, then this may be the result of low work motivation, or ability is not good, or it can be said that the results of the two components of motivation and ability (capacity) is low. An employee who has a high motivation but a low ability to produce a low performance. So is the case with people who actually have a high ability but low motivation, then the performance will also be low. "Performance is defined as the record of outcomes produced on a specified job function or activity during a specified time period". Achievement is a record of the results obtained from the functions of a particular job or activity for a certain period (Bernardin and Rusel in Ruky, 2004: 14 [9])

\subsection{Problem Formulation}

Based on the description on the background of problem above, hence the focus of this research can be formulated as follows:

1. Is the individual characteristics significantly influence employee career development?

2. Is individual characteristic significantly influence employee performance?

3. Is organizational culture significantly influence employee performance?

4. Is organizational culture significantly influence employee career development?

5. Is the performance significantly influence employee career development?

\subsection{Aim and Significance of the Research}

Based on the background of problem and the problem formulation, therefore the purpose and the aim of this research can be described as follows:

1. To test and analyze the influence of individual characteristic on employee performance

2. To test and analyze the influence of individual characteristics on the career development of employees.

3. To test and analyze the influence of organizational culture on employee performance.

4. To test and analyze the influence of organizational culture on employee career development.

5. To test and analyze the performance impact on the career development of employees.

\section{LITERATURE REVIEW}

\subsection{Individual Characteristic}

Individual characteristics that shapes employee behaviors that influence motivation, initiative, performance and career actualization for employees (Robbins, 1996: 109-111 [10]). Suprihanto et al. (2001 [11]), Podsakoff and McKenzie in Sootter (2000 [12]) states that the individual characteristics closely linked to performance, meaning that there is a significant effect of individual characteristics on employee performance. There are four characteristics of an individual as an employee in relation to work. Those four characteristics are: biographical, abilities, personality and learning (Robbins, 1996: 78 [10]). In the biographical characteristics that appear and can be observed on: age, gender, marital status, number of family members (residents) and tenure (Robbins, 1996: 78 [10]). Most likely the relationship between age and performance is an increasingly important issue over the next decade, there is a widespread belief that performance declined with increasing age (Robbins, 1996: 79 [10]).

Therefore, working on character abilities that can be observed is the capacity of individuals to complete various tasks in a job that includes intellectual abilities, skills / emotional skills and physical abilities (Muchlas, 2006:80 [13]).The most necessary element for success in leadership is primarily the job skills / emotional intelligence, while IQ ranks second after emotions intelligence (Goleman, 1999 in Muchlas, 2005: 82 [13]). Personality characteristics observed on a composite of all the ways in which individuals react and interact with other people (Robbins, 1996: 84 [10]).So it is the personality of the integrated self-image and is the total of intrapsychic forces, which create a unique human being, with a specific behavior (Muchlas, 2005:84 [13]). While the characteristics of learning occur at any time and chance. Learning is any relatively permanent change of individual behavior that occurs as a result of life experiences. Occurs when the individual behavioral changes that have occurred in the learning process of the individual. 


\subsection{Organization Culture}

Organizational culture is a form of rules and norm in an organization. These organizational culture is affect all employees in the organization. Organizational culture is already exist in the organization and become their guide to work, so every employee is required to conform to the culture. As a professionally managed organization that organizational culture is expected to improve the performance of employees, so that employees will not have problems in his career. The implementation of the organizational culture required every employee to agree and comply in full, meaningful culture imposed a strong culture. Scooter (2000, $27-28$ [12]) states that a strong organizational culture will be able to motivate and direct the behavior of employees working for the achievement of organizational goals and individual. With the diversity of the ethnic groups, religion and culture, can the employee could receive is determined by the organizational culture of the organization. Cultures evolve naturally when humans together to form a group. A group of members of formal organizations face uncertainty and confusion, its existence as a social system. Growing organization with many different cultures, as a mechanism to manage different environments. Nimran (2004:154 [14]) defines culture or cultures derived from Backer et al. (2002 [15]), "culture is the shared Philosophies, ideologies, values, Assumption, beliefs, expectations, attitude and norms that knit a community together", or culture is a set of philosophies, ideologies , values, assumptions, beliefs, expectations, attitudes and shared norms that bind a society . According to Hodge et al. (2003:264 [16]), culture is there to help people in helping people cope with uncertainty and confusion. Culture is abstract and complex concepts. Culture has two tiers. First, the level of which is observable (visible). Observable characteristics include physical characteristics of the organization such as architecture, art work, patron, clothing, language, history, myths, behaviors, formal rules, rituals and performances. Second, the level of which is unobservable (not visible), includes norms, beliefs, ideologies, values and perceptions. Culture can provide power to the behavior of members of the organization, because it can foster consistency and predictability creativity and manage problems in the organization (Hodge et al., 2003:248 [16]).

\subsection{Performance}

Herriegel et al. (1989:143 [17]) states as a result of the multiplication of individual performance or function of motivation and ability. Performance of the formula is as follows Performance $(\mathrm{P})=$ function (ability and motivation), or performance $=\mathrm{f}$ (ability $\mathrm{x}$ motivation). Gibson $(1984: 95$ [18]) states that the level of employee performance is a measure that can be used to establish a comparison result of performance of duties, responsibilities given by the organization at a certain period and can be used to measure the relative performance or the performance of the organization. Performance appraisal is the process of assessment of personality traits, work habits, and the work of a labor / employee (worker and manager), who considered supporting his performance, which is used as consideration for making decisions about the actions against him in the field of labor (Kotter et al., 2006:287 [19]). According to the Mangkunagara Megginson (2004:69 [20]), seen from the reference point of measurement, there are three criteria for performance measurement, namely: 1 . Performance measurements based on the results of the work by formulating achievement of organizational goals or measure outcomes (end result); 2. Performance measurement is based on the behavior of the measuring means (means) the achievement of objectives (goals) rather than the final outcome (end result). Type of criteria is usually known as BARS (behaviorally Anchored Rating Scales), made from critical incident related to various dimensions of job performance; 3. Judgment based performance measurement which measures achievement based on specific behavioral descriptions, quantity of work, quality of work, job knowledge, cooperation, personal qualities and the like. Employee performance can generally be measured by: 1. Quantity of work, 2 . Quality of work, 3. Knowledge of the work, 4. opinions or statements made, 5. Decisions taken, 6. Planning work, 7. Regional organization of work (Lopez, 1982 [21]). According to Bellows in As'ad (1995:63 [8]), some conditions are better criterion performance measures are more reliable if, realistic, representative, and predictable. Then it was said also that which is commonly used as a criterion measure of performance is the quality, quantity, time spent, positions held, attendance and safety in carrying out the work, which is the most important criterion is the difference between a job with another job. It can be said also that the performance measurement depends on the type of work and goals of the organization concerned.

\subsection{Career Development}

Some understanding of career development by several authors as follows:

- According Dubrin (1982 : 197 [22]) argues that career development, from the standpoint of the organization, is the personnel activity roommates helps individuals plan their future career within the enterprise, in order to help the enterprise and the employee Achieve maximum self-development, which career development is at the core staffing activities that help employees plan for a future career in the company so that the company and the employees concerned can develop myself to the maximum; 
- According to Nawawi (2000 : 289 [23]) career development is formally done in business and focused on continuing to increase and the addition of the ability of a worker ;

- Handoko (2001: 123 [24]) said that career development is a personal improvements one does to achieve a career plan.

- According to Campion et al. (1994 [25]) that the results, younger employees are more interested in beginning a career in the rotation, because they see it as a rotation of the high-level values for their careers than older employees.

\section{RESEARCH METHODOLOGY}

\subsection{Population, Sample and Sampling Technique}

In this study, the entire employee population is a five-star hotel in Surabaya. With consideration of the adequacy of the analysis, this research will be carried out by just taking a portion of the total number of employees' five-star hotel in Surabaya or in other words, do the research sample. The research sample should represent the state of the population, which means that the data obtained is a sample data. Sugiono (2004:56 [26]) says the sample is part of the number and characteristics possessed by the population. What is learned from the samples, the conclusion will be applied to the population; Applied to the sample must be truly representative (representative). Solimun (2007: 4 [27]) states that the sample size for multivariate analysis using is:

1. Recommended sample size is up to 200 and antara100 absolute minimum is 50 , or

2. Equal to 5 to 10 times the number of variables manifest (indicator) or the meter in the model.

So the number of samples that will be used in this study were 100 employees of a five star hotel in Surabaya. With this amount has fulfilled opinions about the sample size has been described previously, including to meet the ideal in the analysis of the SEM models, as described by Ferdinand (2002:47 [28]) states that the sample size as in other statistical methods for estimating error generating basic sampling. In this study the sampling technique is proportional random sampling. According to Nazir (2004:277 [29]), proportional random sampling that samples drawn from population groups, but not all members of the group become members of the sample population. Only some members of a subpopulation of the sample members. Population of each member of the group has a large probability proportional to the relative of the groups included in the sub- sample.

Collecting data in this study as the primary data source is done by creating a structured questionnaire to obtain data on the studied variables of employees' five star hotels in Surabaya. Data collection was also conducted with unstructured interviews and direct observation in order to further refine the analysis, particularly regarding individual characteristics, values, organizational culture, performance and career development of employees of a five star hotel in Surabaya. To scale the data, this study uses a Likert scale were classified as interval data. Scale interval data used has a range of 1 to 5 , where 1 is represent the lowest and 5 is the highest.

Identification of Variables:

1. Exogenous variables

a. Individual characteristics

b. Organization culture

2. Endogenous variables

a. Performance

b. Career development

\subsection{Structural Model Analysis}

\section{ANALYSIS AND DISCUSSION}

Standardized coefficient is used for a path coefficient, these coefficient is used as a standard analysis in SEM. Standardized coefficient, is used as the coefficient refer to the contribution net of a direct relationship between variables. Hypotheses testing research conducted by t-test on each of the direct influence of the partial path. Summary of hypotheses testing result as shown in Fig. 1 and Tab. 1 below. 


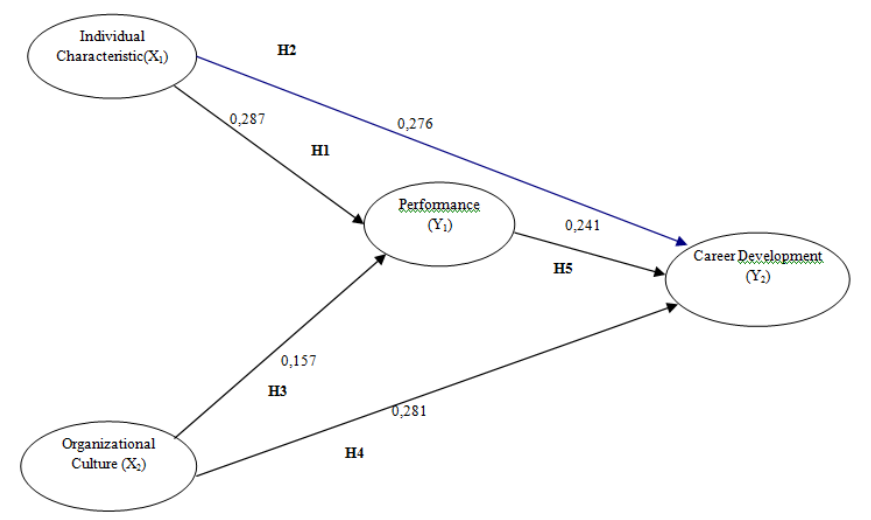

Fig 1. Path analysis of hypotheses result

Fig. 1, shows the path coefficients for the effect of individual characteristics $\left(\mathrm{X}_{1}\right)$ to employee performance $\left(\mathrm{Y}_{1}\right)$ of 0.287 . This means that if the individual characteristics $\left(\mathrm{X}_{1}\right)$ moved up one unit of the employee's performance $\left(\mathrm{Y}_{1}\right)$ will increase by 0.287 units. Conversely, if the individual characteristics $\left(\mathrm{X}_{1}\right)$ down one unit, then the employee's performance $\left(\mathrm{Y}_{1}\right)$ will decrease by 0.287 units. In practical terms, this means that any improvement of the individual characteristics of the hotel will improve employee performance five-star hotel in Surabaya.

The path coefficient for the effect of individual characteristics $\left(\mathrm{X}_{1}\right)$ to career development $\left(\mathrm{Y}_{2}\right)$ of 0.276. This means that if the individual characteristics $\left(\mathrm{X}_{1}\right)$ moved up one unit of the career development $\left(\mathrm{Y}_{2}\right)$ will increase by 0.276 units. Conversely, if the individual characteristics $\left(\mathrm{X}_{1}\right)$ down one unit, then the career development $\left(\mathrm{Y}_{2}\right)$ will fall by 0,276 units. In practical terms, this means that any improvement of individual characteristics will enhance employee career development five-star hotel in Surabaya.

Path coefficients on the influence of organizational culture $\left(\mathrm{X}_{2}\right)$ on the performance $\left(\mathrm{Y}_{1}\right)$ of 0.157 . This means that if the culture of the organization $\left(\mathrm{X}_{2}\right)$ moved up one unit of the employee's performance $\left(\mathrm{Y}_{1}\right)$ will be increased by 0,157 units. Conversely, if the organizational culture $\left(\mathrm{X}_{2}\right)$ down one unit, then the employee's performance $\left(\mathrm{Y}_{1}\right)$ will fall by 0,157 units. In practical terms, this means that any improvement of cultural organization in the hotel will improve employee performance five-star hotel in Surabaya.

Path coefficients on the influence of organizational culture $\left(\mathrm{X}_{2}\right)$ on the career development $(\mathrm{Y} 2)$ of 0,281 . This means that if the culture of the organization $\left(\mathrm{X}_{2}\right)$ moved up one unit of the career development $\left(\mathrm{Y}_{2}\right)$ will be increased by 0,281 units. Conversely, if the organizational culture $\left(\mathrm{X}_{2}\right)$ down one unit, then the career development $\left(\mathrm{Y}_{2}\right)$ will fall by 0,281 units. In practical terms, this means that any improvement of organizational culture hotels will increase employees' career development of a five star hotel in Surabaya.

The influence of the path coefficient of performance $\left(\mathrm{Y}_{1}\right)$ to career development $\left(\mathrm{Y}_{2}\right)$ of 0.241 . This means that if the performance $\left(\mathrm{Y}_{1}\right)$ moved up one unit of the career development $\left(\mathrm{Y}_{2}\right)$ will increase by 0.241 units. Conversely, if performance $\left(\mathrm{Y}_{1}\right)$ down one unit of the career development $\left(\mathrm{Y}_{2}\right)$ will decrease by 0.241 units. In practical terms, this means that any improvement of the performance of employees will increase employees' career development five-star hotel in Surabaya.

\subsection{Hypotheses Testing Result}

Hypothesis testing is done by t-test in each of the direct influence of the partial path. Table 1, presents the results of hypothesis testing direct influence. Results of hypothesis testing pathways directly influence can also be seen in the results of testing hypothesis path diagram in Fig. 1.

Table 1. Hypotheses Training Result

\begin{tabular}{|c|c|c|c|c|}
\hline Variables & Dependent Variables & $\begin{array}{l}\text { Path } \\
\text { Coefficient }\end{array}$ & p-value & Information \\
\hline Individual characteristic $\left(\mathrm{X}_{1}\right)$ & Performance $\left(\mathrm{Y}_{1}\right)$ & 0,287 & 0,001 & Significant \\
\hline Individual characteristic $\left(\mathrm{X}_{1}\right)$ & Career Development $\left(\mathrm{Y}_{2}\right)$ & 0,276 & 0,012 & Significant \\
\hline Organization Culture $\left(\mathrm{X}_{2}\right)$ & Performance $\left(\mathrm{Y}_{1}\right)$ & 0,157 & 0,009 & Significant \\
\hline Organization Culture $\left(\mathrm{X}_{2}\right)$ & Career Development $\left(\mathrm{Y}_{2}\right)$ & 0,281 & 0,006 & Significant \\
\hline Performance $\left(\mathrm{Y}_{1}\right)$ & Career Development $\left(\mathrm{Y}_{2}\right)$ & 0,241 & 0,015 & Significant \\
\hline
\end{tabular}

\subsection{Variable Relationship}

From the relationship between variables, we can clearly know which variables are significant and the variables that is not significant and the influence is low. The relation of each variables can be described as follows:

Hypothesis 1: Individual characteristic $\left(\mathrm{X}_{1}\right)$ significantly influence to Performance $\left(\mathrm{Y}_{1}\right)$ 
Table 1 shows that the path coefficients of the variables of individual characteristics $\left(\mathrm{X}_{1}\right)$ to variable performance $\left(\mathrm{Y}_{1}\right)=0.287$ with probability $=0.001$ or $P>0.05$. From this hypothesis result we can conclude that individual characteristics have a significant effect on the performance of the employee turns out significantly, it means the better the individual characteristics of the employee, the higher the performance.

Hypothesis 2: Individual Characteristic $\left(\mathrm{X}_{1}\right)$ significantly influence to career development $\left(\mathrm{Y}_{2}\right)$ Table 1 shows that the path coefficients of the variables of individual characteristics $\left(\mathrm{X}_{1}\right)$ to variable employee career development $\left(\mathrm{Y}_{2}\right)=0.276$ with probability $=0.012$ or $P>0.05$. These means that number one hypothesis in this study, which states that the individual characteristics significantly influence employee career development apparently significant, this meaning that the better the individual characteristics of the employee, the higher the career development of employees.

Hypothesis 3: Organizational culture $\left(\mathrm{X}_{2}\right)$ significantly influence to performance $\left(\mathrm{Y}_{1}\right)$

From Table 1 are known that SEM analysis of organizational culture variables $\left(\mathrm{X}_{2}\right)$ and the performance $\left(\mathrm{Y}_{1}\right)$ path coefficient 0.157 and p-value of 0.009 or $P>0.05$, there is enough empirical evidence to accept the hypothesis that the "Cultural organization $\left(X_{2}\right)$ influential significant impact on performance $\left(Y_{1}\right)$ ". These fact means the better the culture of the organization, the better the performance of employees.

Hypothesis 4: Organizational culture $\left(\mathrm{X}_{2}\right)$ significantly influence to career development $\left(\mathrm{Y}_{2}\right)$

From the result of SEM analysis, the organizational culture variables $\left(\mathrm{X}_{2}\right)$ and the career development $\left(\mathrm{Y}_{2}\right)$ path coefficient value is 0.281 and $p$-value 0.006 or $P>0.05$, there is enough empirical evidence to accept the hypothesis that the "Cultural organization $\left(X_{2}\right)$ significantly influence the development of career $\left(Y_{2}\right)$ ". The meaning of this result is the better the culture of the organization, the higher the career development of employees.

Hypothesis 5: Performance $\left(\mathrm{Y}_{1}\right)$ significantly influence to career development $\left(\mathrm{Y}_{2}\right)$

From the result of SEM analysis in table 1, the performance variables $\left(\mathrm{Y}_{1}\right)$ and the career development of employees. $\left(\mathrm{Y}_{2}\right)$ path coefficient 0.241 and $p$-value of 0.015 or $P>0.05$. Therefore there is enough empirical evidence to accept the hypothesis that the performance $\left(\mathrm{Y}_{1}\right)$ significantly influence employee career development $\left(\mathrm{Y}_{2}\right)$. There result means that the better the performance, the higher the career development of employees.

\section{CONCLUSION}

From the research hypothesis, observational data and the result as described above, this research can be conclude as follows:

1. Individual characteristics $\left(\mathrm{X}_{1}\right)$ have a significant effect on performance $\left(\mathrm{Y}_{1}\right)$. These mean that the better the individual characteristics of the employee, the higher the performance. In this case the individual characteristics of each employee attached to a five-star hotel Surabaya to always improve its performance.

2. Individual characteristics $\left(\mathrm{X}_{1}\right)$ significantly influence employee career development $\left(\mathrm{Y}_{2}\right)$, meaning that the better characteristics of the individual, the higher the career development of employees. The significance of the presence of a positive relationship with the individual characteristics of employees' career development, in this case the characters are owned by employees of a five-star hotel Surabaya direct impact on career development.

3. Organizational culture $\left(\mathrm{X}_{1}\right)$ have a significant effect on performance $\left(\mathrm{Y}_{1}\right)$. Furthermore this meaning that the better the culture of the organization, the better the performance of employees. In this case the employee perceptions of culture adopted a five-star hotel in Surabaya is positive to improve its performance.

4. Organizational culture $\left(\mathrm{X}_{1}\right)$ a significant effect on performance $\left(\mathrm{Y}_{1}\right)$, meaning that the better the culture of the organization, the better the performance of employees. In this case the employee perceptions of culture adopted a five-star hotel in Surabaya is positive to improve its performance.

5. Organizational culture $\left(\mathrm{X}_{2}\right)$ significantly influence career development $\left(\mathrm{Y}_{2}\right)$. These mean that the better the culture of the organization, the higher the career development of employees. Significance of the presence of a positive relationship culture that applied a five-star hotel Surabaya direct impact on the career development of employees.

6. Performance $\left(\mathrm{Y}_{1}\right)$ significantly influence employee career development. $\left(\mathrm{Y}_{2}\right)$, meaning that the better the performance, the higher the career development of employees. In this case a five star hotel employee Surabaya always improve performance for career development

7. Results of this study can contribute to the management of the five star hotels in Surabaya as consideration for formulating company policy in particular efforts to maintain and improve the company's performance through individual characteristics and organizational culture. 
8. Results of this study can be explained in an integrative way that the performance and career development of employees five star hotel in Surabaya is influenced by individual characteristics and organizational culture.

\section{REFERENCES}

[1] Soekadijo, RG. 1996. Anatomi Pariwisata: Memahami Pariwisata sebagai”Systemic Linkage”. Jakarta: PT. Gramedia Pustaka

[2] Foster, Dennis L., 2000. First Class An Introduction To Travel and Tourism. Edisi Bahasa Indonesia. Jakarta: PT. Raja Grafindo Persada.

[3] Schuster, Frederick E. 1999. Organizational Culture and Performance: a Cross-Cultural Study. Florida 33431, USA., pp. 1-26.

[4] Robbins, Stephen P., and De Cenzo, David A. 2004. Organizational Behavior. New Jersey: Prentice Hall, Inc Saddle River.

[5] Arep, Ishak \& Tanjung, Hendri, 2004. Manajemen Motivasi. Jakarta: PT Grasindo.

[6] O'Reilly, C.A., Chatman, J.A., and Caldwell, D.F., 1991. people and Organizational Culture: A Profile Comparison Approach to Assessing Person-Organization fit. Academy of Management Journal, 34:487-516.

[7] Luthans, Fred. 1996. Organizational Behavior, Sixth Edition, Singapore: Mc Grow Hill Book Co.

[8] As'ad, Moch, 1995. Psikologi Industri. Edisi kelima. Cetakan kedua. Yogyakarta: Liberty.

[9] Ruky, Achmad S. 2004. Sistem Manajemen Kinerja. Jakarta: PT Gramedia Pustaka Utama.

[10] Robbins, Stephen.1996. Organization Theory, Third Edition. New York: Prentice-Hall, Inc.

[11] Suprihanto, John, 2001. Penilaian Kinerja dan Pengembangan Karyawan. Yogyakarta: BPFE-Yogyakarta.

[12] Scotter, J.R.V. 2000. "Relationships of Task Performance and Contextual Performance With Turnover, Job Satisfaction, and Affective Commitment", Human Resource Management Review, Vol 10, No. I, pp. 76-95.

[13] Muchlas, Makmuri, 2005. Perilaku Organisasi. Yogyakarta: Gadjah Mada University Press.

[14] Nimran, Umar. 2004. Perilaku Organisasi. Surabaya: Penerbit Citramedia.

[15] Baker, Kathryn A. 2002. Organizational Culture. Journal of Organizational Culture No.20, pp. 1-11.

[16] Hodge, B.J., Anthony, William P., Gales, Lawrence. 2003. Organization Theory. Sixth Edition. New Jersey: Prentice-Hall, Pearson Education, LTD.

[17] Hellriegel, D., Slocum, J., and Woodman, R.W. 1989. Organizational Behavior. Fifth edition, Singapore. Herper \& Row Pulisher.

[18] Gibson, James L., Ivancevich, John M., and Donnelly Jr., James H., Jr. 1984. Organisasi dan Manajemen. Terjemahan Tim penerbit Erlangga. Jakarta: Penerbit Erlangga.

[19] Kotter, John P. and James L. Heskett. 2006. Budaya Korporat dan Kinerja. Edisi Bahasa Indonesia, diterjemahkan: Hardaniati, Susi Diah; Sulaksana, Uyung. New York: Free Press. Penerbit: SAGA.

[20] Mangkunegara, A.A. Anwar, Prabu. 2004. Manajemen Sumber Daya Manusia Perusahaan. Bandung : Penerbit PT. Remaja Rosdakarya.

[21] Lopez, Elsa, 1982. A Test of The Self Consistency Theory of The Job Performance-Job Satisfaction Relationship, Academic of Management, Journal. Vol.25, No.2, pp. 335-348.

[22] Dubrin, Andrew J, 1982. Personnel and Human Resources Management, California: Kent Publishing Company.

[23] Nawawi, Hadari, 2000. Manajemen Sumber Daya Manusia: Untuk Bisnis Yang Kompetitif. Yogyakarta: Gajah Mada University Press.

[24] Handoko, T. Hani, 2001. Manajemen Personalia dan Sumber Daya Manusia. Yogyakarta: BPFE-Yogyakarta.

[25] Campion, Michael A., Cheraskin, Lisa, Stevens, and Michael J., 1994. "Career-Related Antecedents and Outcomes of Job Rotation", Academy of Management Journal, Vol. 37, No. 6, pp. 1518-1542

[26] Sugiono, 2004. Statistika untuk Penelitian. Bandung: CV. Alfabeta.

[27] Solimun, 2007. Analisis Multivariant, Pendekatan Mutahir, Malang Universitas Brawijaya.

[28] Ferdinand, Augusty. 2002. Structural Equation Modeling, Semarang: Dalam Penelitian Manajemen BPUNIP.

[29] Nazir, Moh, 2004. Metode Penelitian. Jakarta: Ghalia Indonesia. 